The Europeanization of the World 



\title{
The Europeanization of the World
}

\author{
On the Origins of \\ Human Rights and Democracy \\ JOHN M. HEADLEY
}


Copyright (c) 2008 by Princeton University Press Published by Princeton University Press, 41 William Street, Princeton, New Jersey 08540

In the United Kingdom: Princeton University Press, 3 Market Place, Woodstock, Oxfordshire OX20 1SY

All Rights Reserved

Library of Congress Cataloging-in-Publication Data

Headley, John M.

The Europeanization of the world : on the origins of human rights and democracy / John M. Headley

p. $\mathrm{cm}$.

Includes bibliographical references and index.

ISBN: 978-0-691-13312-6 (hardcover : alk. paper)

1. Democracy. 2. Human rights. 3. GlobalizationPolitical aspects. I. Title.

JC423.H425 2007

321.8-dc22 2007010470

British Library Cataloging-in-Publication Data is available

This book has been composed in Palatino

Printed on acid-free paper. $\infty$

press.princeton.edu

Printed in the United States of America

$\begin{array}{llllllllll}1 & 3 & 5 & 7 & 9 & 10 & 8 & 6 & 4 & 2\end{array}$ 
Remota itaque iustitia, quid sunt regna nisi magna latrocinia?

-Aug. De civ. Dei, IV.4 

For my many grandnieces and grandnephews and for their generation, lest they ignore, forget, or never even encounter 
